UDC 628.1

DOI: https://doi.org/10.20535/2218-93002612020199279

\title{
EFFICIENCY ASSESSMENT OF THE ADDITIONAL DRINKING WATER TREATMENT WITH HOUSEHOLD CARTRIDGES
}

\author{
A. P. Bolshak ${ }^{1 *}$, T. Ye. Mitchenko ${ }^{1}$, A. O. Mitchenko ${ }^{2}$ \\ ${ }^{1}$ National Technical University of Ukraine «Igor Sikorsky Kyiv Polytechnic Institute», \\ Kyiv, Ukraine \\ ${ }^{2}$ Ecosoft Water International Bvba, Gent, Belgium \\ *e-mail: annebolshak@gmail.com
}

The purpose of this study was to rate the performance of cartridges for commercially available pitcher filters. The design features and composition of cartridge loadings of industrial pitcher filters were studied and a comparative study of their performance in terms of water purification from chlorine, hardness ions and organic compounds was made. It is established that all the studied industrial cartridges are physicochemical analogues and differ only in design parameters, and the main factor that influences the degree of water purification from pollutants is the contact time of water with the cartridge loading. It was also found that the information provided by the industrial cartridge manufacturers about the effectiveness of water purification from impurities is untrue and in fact is overstated. The analysis of information on the work of industrial cartridges showed the possibility of a significant increase in their efficiency by creating optimal operating conditions. Requirements have been formulated, that have to be met by the filter cartridge with the optimal properties and the main variable and constant factors that affect the performance of the cartridges are identified.

Keywords: pitcher filter, cartridge, low acid cation exchanger, activated carbon, chlorine, water hardness, permanganate oxidation, contact time, water purification efficiency.

The quality of drinking water in Ukraine does not always meet the requirements set out in the regulatory document DSanPin 2.2.4-171-10 «Hygienic requirements for drinking water intended for human consumption». This applies both to water from centralized sources of water and to decentralized ones (DSanPin 2.2.4-171-10, 2010).

The most common pollutants that significantly impair the organoleptic and physico-chemical properties of tap water are substances widely used in the process of its centralized purification chlorine and its compounds, aluminum, iron, as well as natural surface water pollutants - humic compounds, the presence of which causes increased color of the water. To remove such unwanted impurities, household drinking water filters with replaceable cartridges are commonly used, the most common of which are the so-called pitchers. These filters, as well as replaceable cartridges, attract customers with low cost, mobility, modern design and ease of use. At the same time, the efficiency of water purification with their help does not always meet the promises of manufacturers and users' expectations (Mitchenko (Eds.), 2019).

There is a large number of pitcher filters from different manufacturers on the market, each of which is equipped with cartridges for different purposes - for removing chlorine, hardness ions, discoloration of water, removal of various toxic metals and organic compounds, and most often for simultaneous cleaning from all the impurities listed above. Information about the type and performance of the cartridges is provided by the manufacturers, and the degree of its reliability depends on the honesty of the latter (Maletsky, 2012).

In this study there were compared cartridges for household pitcher-filters by different manufacturers to evaluate their performance and determine the factors that affect it. 


\section{Experimental technique}

During the work, the impact of the design features, the composition of the loading and the performance of the cartridges on the efficiency of water purification from pollutants, that cause the most complaints from users of tap water, were evaluated.

The technique of the experiment was to let the tap water of Kyiv through a pitcher-filter with taking samples for analysis after $10,50,100,150 \mathrm{dm}^{3}$. In addition, before the analysis of water samples that passed through the pitcher-filter, samples of the source water were taken for analysis. The composition of the source water is given in Table 1 (Bolshak and Mitchenko, 2019).

Table 1. The composition of the source water.

\begin{tabular}{|l|c|c|}
\hline \multirow{2}{*}{\multicolumn{1}{c|}{ Indicator }} & \multicolumn{2}{c|}{ Value } \\
\cline { 2 - 3 } & $\begin{array}{c}\text { In the source } \\
\text { water }\end{array}$ & $\begin{array}{c}\text { Requirements of } \\
\text { DSanPin }\end{array}$ \\
\hline $\mathrm{pH}$ & $7.2-7.7$ & $6.5-8.5$ \\
\hline Color index, degrees & $30-37$ & $<20$ \\
\hline Turbidity, $\mathrm{mg} / \mathrm{dm}^{3}$ & $0.4-0.6$ & $<0.58$ \\
\hline Hardness, $\mathrm{meq} / \mathrm{dm}^{3}$ & $4.5-4.7$ & $<14$ \\
\hline Chlorine $(\mathrm{common}), \mathrm{mg} / \mathrm{dm}^{3}$ & $0.45-0.55$ & $<0.5$ \\
\hline Iron, $\mathrm{mg} / \mathrm{dm}^{3}$ & $0.086-0.2$ & $<0.2$ \\
\hline Permanganate oxidation, $\mathrm{mgO} / \mathrm{dm}^{3}$ & $4.2-5.6$ & $<5$ \\
\hline
\end{tabular}

Since the concentration of chlorine in the tap water was low $\left(<0.05 \mathrm{mg} / \mathrm{dm}^{3}\right)$ and unstable during the experiment, model water with a chlorine concentration of $0.5 \mathrm{mg} / \mathrm{dm}^{3}$ was prepared.

To evaluate the performance of the cartridges, there were determined such parameters as: filtration rate, water contact time with loading, and the degree of improvement of purified water quality compared to source water (purification efficiency, a) by the indicators given in table 1, the values of which exceeded the requirements: color index and permanganate oxidation (PO), as well as chlorine content, the increased content of which affects the organoleptic properties of water, and hardness. Because the chromaticity and permanganate oxidation are correlated with each other, the PO is chosen as the benchmark, characterizing the content of organic and mineral substances in water, that are oxidized by one of the strongest chemical oxidizers, potassium permanganate, under certain conditions. The PO index describes more broadly the content of organic matter in water in compare with the color index, and in turn covers the indicator of color.

The contact time of water with the cartridge loading layer $\left(t_{\text {cont }}\right)$ was determined by the formula:

$$
t_{\text {cont }}=\frac{V_{l}}{\vartheta}
$$

where $\mathrm{V}_{1}$ - loading volume $\left(\mathrm{cm}^{3}\right), v$ - rate of water flow through the cartridge $\left(\mathrm{cm}^{3} / \mathrm{min}\right)$.

\section{Results and discussion}

The objects of the study were six samples of commercially available cartridges by the five famous manufacturers that are the most spread on Ukrainian market.

During the experiment cartridges were opened and as a result their design features, cartridge loading composition, volumes of cartridges and the loading itself were visually estimated. The actual design characteristics of the cartridges and the loading features are presented in Table 2. All cartridges contained coconut activated carbon and slightly acidic cation exchanger as part of the loading. As a top drainage, all cartridges contain a polypropylene grid that prevents the removal of filter materials. 
Table 2. Features of cartridge loadings from different manufacturers.

\begin{tabular}{|c|c|c|c|l|}
\hline Cartridge & $\begin{array}{c}\text { Cartridge } \\
\text { volume, } \mathrm{cm}^{3}\end{array}$ & $\begin{array}{c}\text { Volume of cartridge } \\
\text { loading, } \mathrm{cm}^{3}\end{array}$ & $\begin{array}{c}\text { Loading } \\
\text { ratio, } \%\end{array}$ & \multicolumn{1}{|c|}{ Lower drainage materials } \\
\hline I & 152 & 144 & 96 & Non-woven fabric \\
\hline II & 170 & 118 & 69 & Non-woven fabric \\
\hline III & $117-120$ & 76 & 63 & Non-woven fabric \\
\hline IV & $200-210$ & $\begin{array}{c}\text { Active carbon }+ \\
\text { Ion exchanger }-85 \\
\text { Fiber }-65\end{array}$ & 75 & $\begin{array}{l}\text { Non-woven partition. On the } \\
\text { bottom, top of the cartridge } \\
\text { and between the loading } \\
\text { layers there are 3 plastic } \\
\text { lattice partitions }\end{array}$ \\
\hline V & 117 & 100 & 85 & Foam rubber \\
\hline VI & 175 & 136 & 77 & Non-woven fabric \\
\hline
\end{tabular}

The photos of the cartridge loadings that listed in Table 2 are shown on Fig. 1.

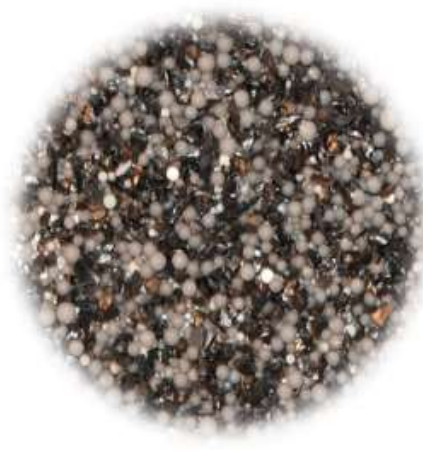

I

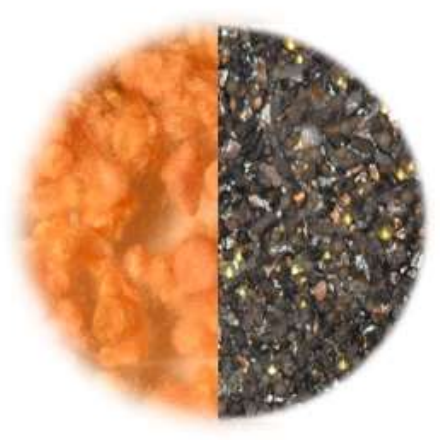

IV

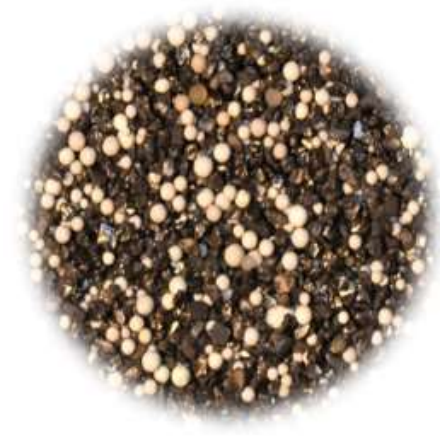

II

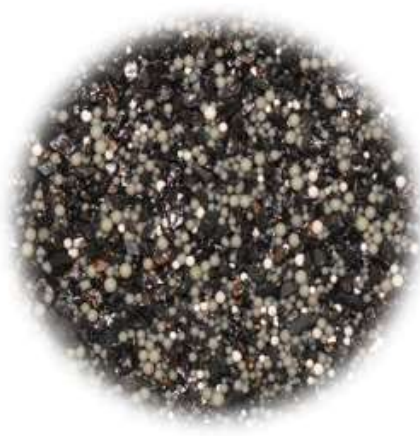

$\mathrm{V}$

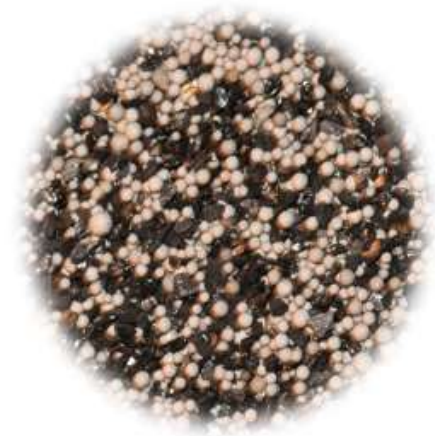

III

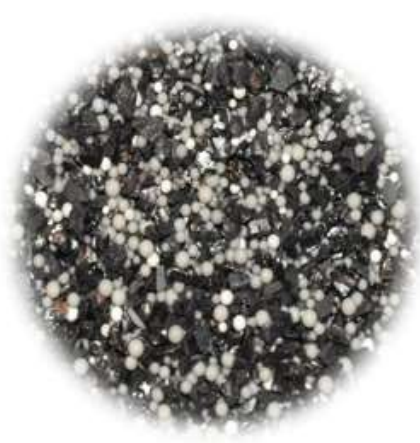

VI

Fig. 1. Cartridges loadings I - VI.

From the data of Table 2 and figure 1 it is seen that the main content of the cartridge loading by different manufacturers is similar and consists of coconut activated carbon and slightly acid cation exchanger as ion-exchange material. An exception is the IV cartridge, the loading of which consists of 2 layers: the main filter mixture (from activated carbon and ion exchanger) and a layer of fibrous material. Therefore, all the tested cartridges are practically complete physico-chemical analogues. The ratio of components coal: ion-exchanger in the mixture also slightly differs in the different cartridges and is $(1.2-1.3): 1$ for all the tested samples. At the same time, the cartridge sizes and, accordingly, the loading volumes differ substantially and range from 75 to $150 \mathrm{~cm}^{3}$, and the cartridge loading rate also varies from 63 to $96 \%$. 
The results of the study of the filtering characteristics of the cartridges are presented on Figures 2 - 4 and Table 3.

Figure 2 shows the graphs of filtration rate change on the cartridges, which shows that in almost all cartridges the filtration rate in the interval of $10-150 \mathrm{dm}^{3}$ of passed water decreases slightly and remains practically stable. An exception is the cartridge $\mathrm{V}$, where there is a sharp decrease in speed during the passage of $10-100 \mathrm{dm}^{3}$ of water.

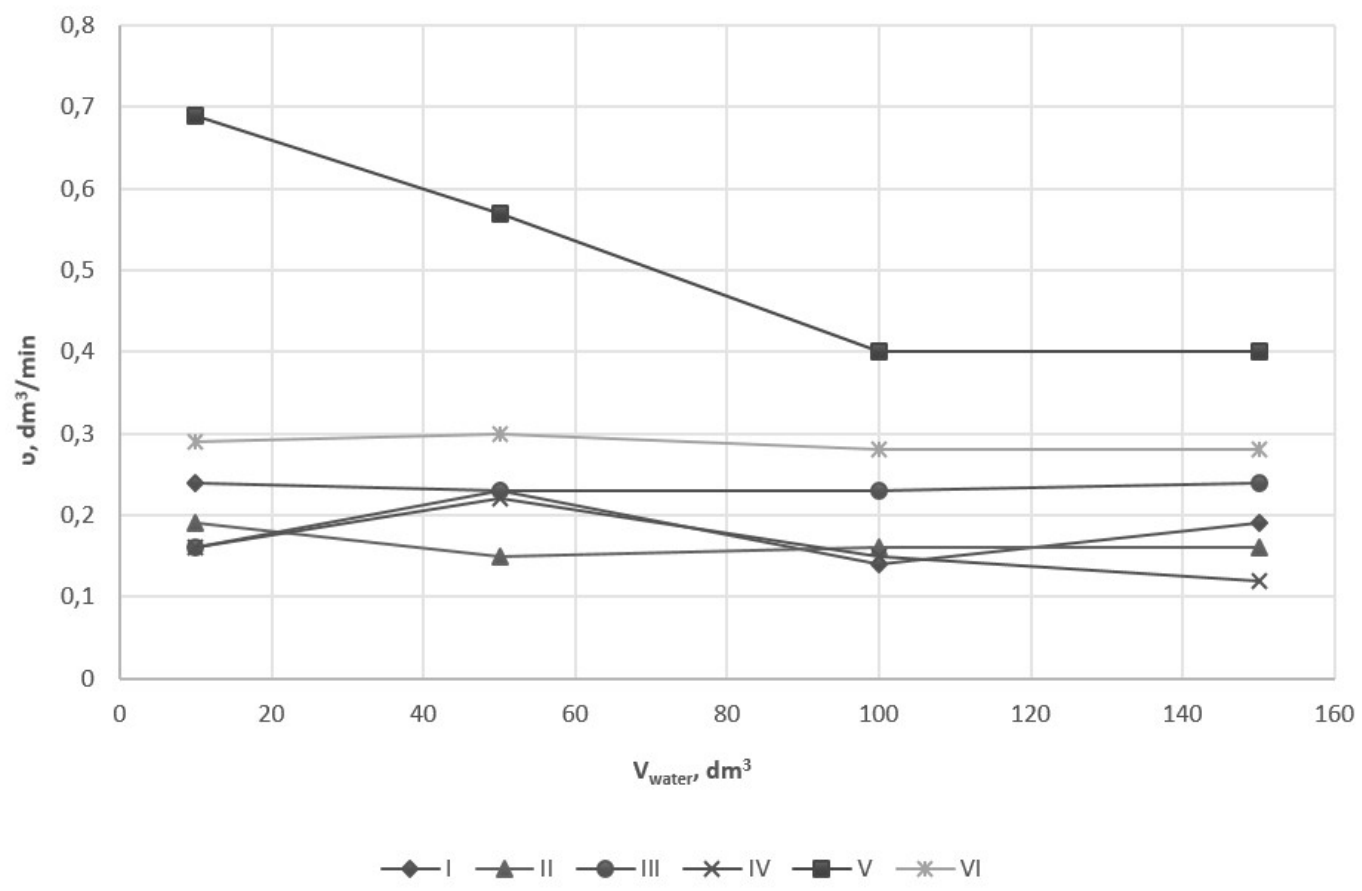

Fig. 2. Dependence of filtration rate $\left(v, \mathrm{dm}^{3} / \mathrm{min}\right)$ from the volume of water passed through the cartridges by different manufacturers.

Figure 3 shows the graphs of the degree of water purification from pollutants during the passage of $10-150 \mathrm{dm}^{3}$ of water on cartridges I - VI.

Table 3. Water purification efficiency on cartridges by different manufacturers (averaged over $\left.150 \mathrm{dm}^{3}\right)$.

\begin{tabular}{|c|c|c|c|c|c|c|}
\hline \multirow{2}{*}{ Cartridge } & \multicolumn{3}{|c|}{$\begin{array}{l}\text { The average degree of } \\
\text { purification for } 150 \mathrm{dm}^{3}, \%\end{array}$} & \multirow{2}{*}{$\begin{array}{l}\text { Loading } \\
\text { volume, } \mathrm{dm}^{3}\end{array}$} & \multirow{2}{*}{$\begin{array}{l}\text { Filtration rate, } \\
\mathrm{dm}^{3} / \mathrm{min}\end{array}$} & \multirow[t]{2}{*}{$t_{\text {cont }}, \min$} \\
\hline & $\mathrm{Cl}$ & $\mathrm{PO}$ & Hardness & & & \\
\hline $\mathrm{I}$ & 55.3 & 7.2 & 26.6 & 0.144 & 0.19 & 0.76 \\
\hline II & 56.8 & 13.7 & 15.9 & 0.118 & 0.16 & 0.74 \\
\hline III & 44.1 & 8.0 & 14.4 & 0.076 & 0.23 & 0.33 \\
\hline IV & 57.3 & 15.9 & 16.6 & 0.150 & 0.16 & 0.94 \\
\hline $\mathrm{V}$ & 38.8 & 6.3 & 10.8 & 0.100 & 0.52 & 0.19 \\
\hline VI & 53.8 & 13.8 & 17.3 & 0.140 & 0.29 & 0.48 \\
\hline
\end{tabular}

As can be seen from Figure 3, in general, during the filtering of water on cartridges I-VI, during 1$150 \mathrm{dm}^{3}$, the efficiency of water purification from chlorine, hardness and PO gradually decreases as the filtering materials of cartridge loading are depleted. It should be noted that the efficiency of water purification from pollutants reaches a maximum during 10-50 $\mathrm{dm}^{3}$ of passed water and further significantly decreases. Exceptional case of increasing of efficiency of water purification from PO on cartridge $V$ in case of passage of $50-150 \mathrm{dm}^{3}$ of water can be explained by sharp decrease of the speed of water passing through the cartridge loading, as shown on Fig. 2. 
1
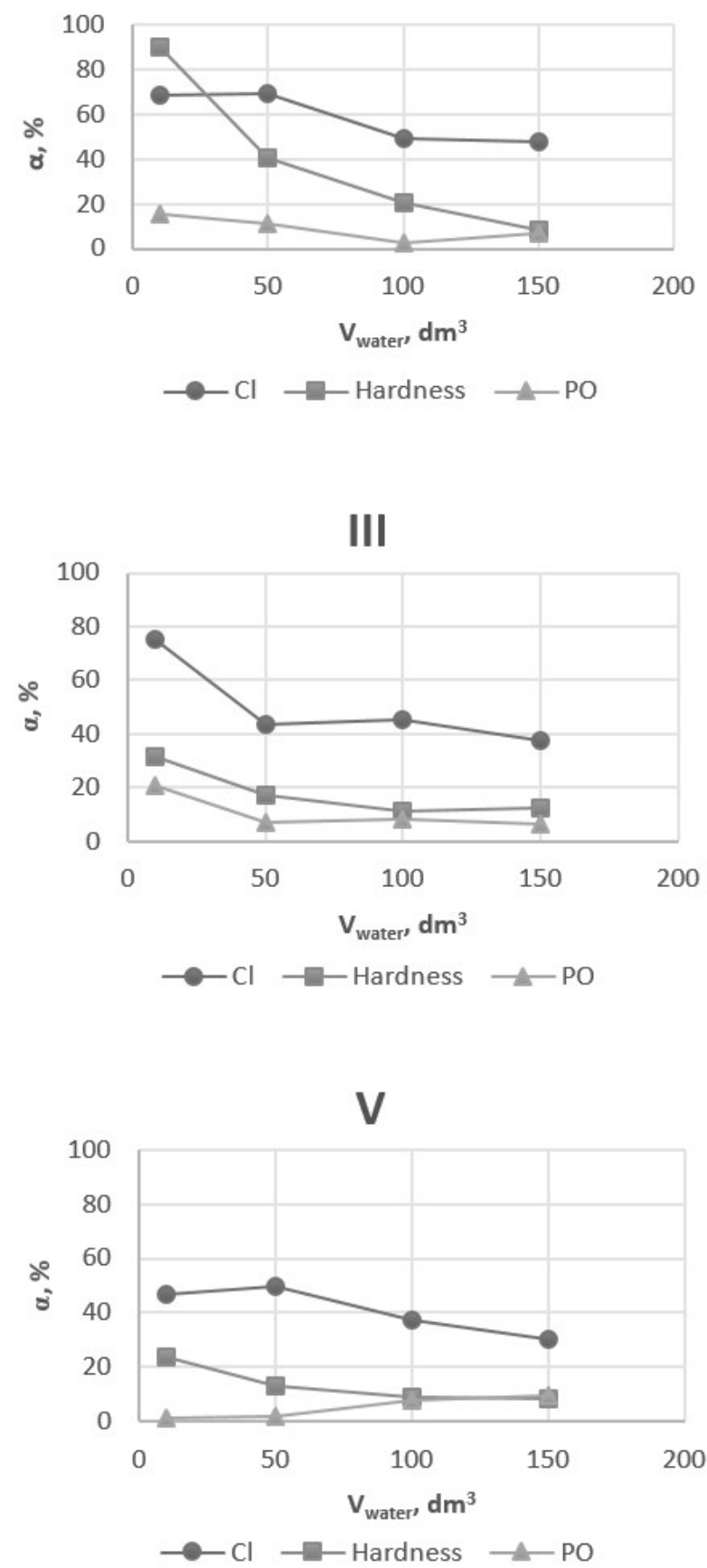

II

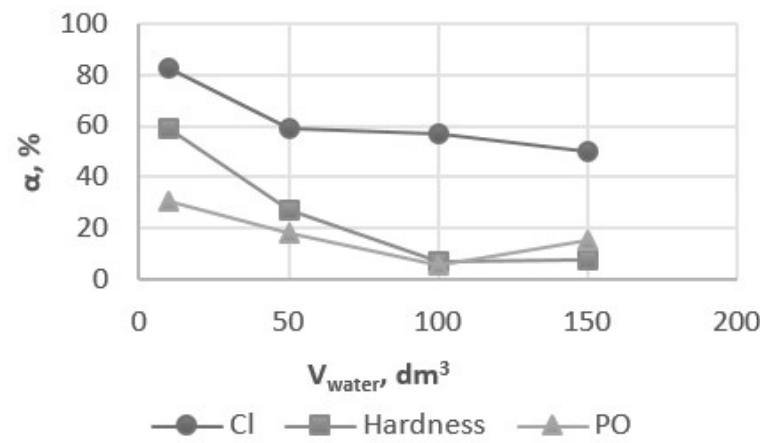

IV
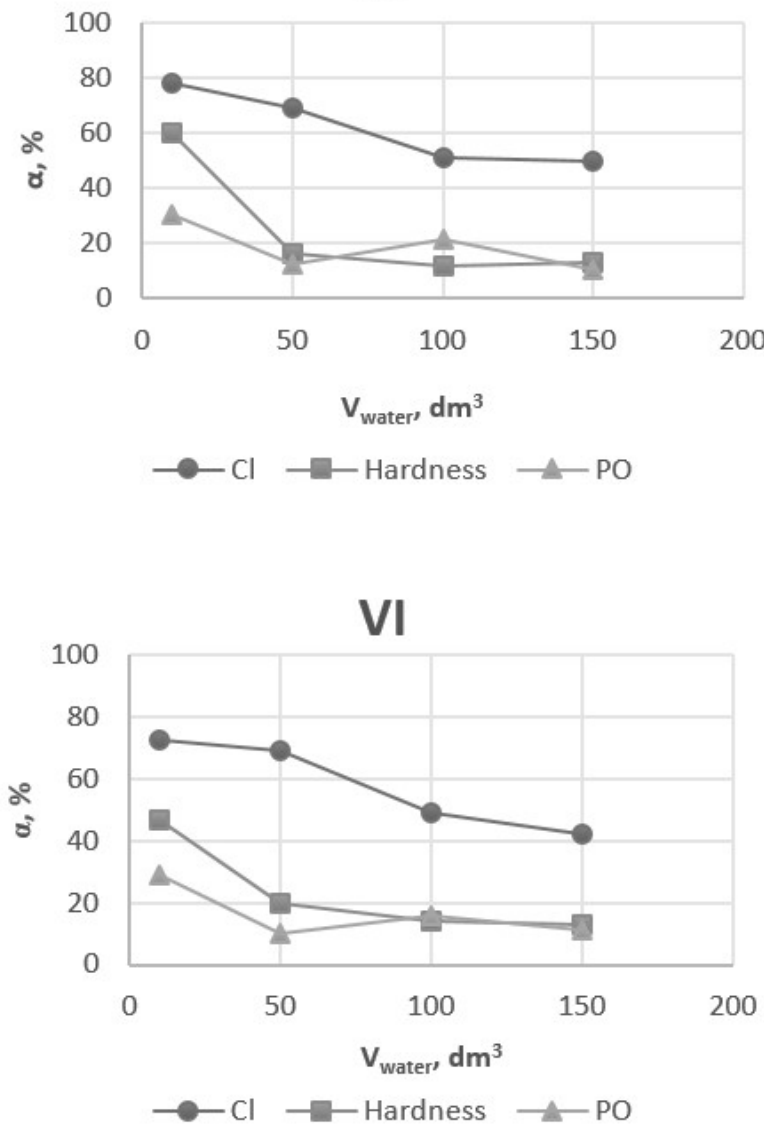

Fig. 3. Dependence of the degree of purification of water from pollutants $(a, \%)$ on the volume of leaked water (inputs, $\mathrm{dm}^{3}$ ) on cartridges I-VI.

Evaluation of the efficiency of the studied cartridges towards chlorine showed that the average degree of reduction of this indicator in the range of $1-150 \mathrm{dm}^{3}$ of passed water is $39-57 \%$ for all cartridges. However, after passing the first $10 \mathrm{dm}^{3}$ of water, the efficiency of its purification reaches $83 \%$, and after passing $150 \mathrm{dm}^{3}-30-50 \%$.

The evaluation of the efficiency of the studied cartridges towards oxidation and hardness showed that the degree of decreasing of these parameters in the range of $1-150 \mathrm{dm}^{3}$ of the passed water does not exceed $26 \%$. In this case, after passing the first $10 \mathrm{dm}^{3}$ of water, the efficiency of its purification from hardness reaches $90 \%$, after passing $150 \mathrm{dm}^{3}-6-13 \%$, and during purification of water from the PO, these indicators reach $30 \%$ after passing $10 \mathrm{dm}^{3}$ of water, and $7-15 \%$ - after passing $150 \mathrm{dm}^{3}$. 
The largest decrease of the concentration of all the studied impurities occurs in the interval of 1-50 $\mathrm{dm}^{3}$ of passed water for all tested cartridges, and then significantly reduced, primarily due to the subsequent depletion of the sorption capacity of the loading components.

The dependence of the average of $150 \mathrm{dm}^{3}$ values of the degree of water purification (from pollutants) on the time of contact between water and loading is shown on Figure 4.

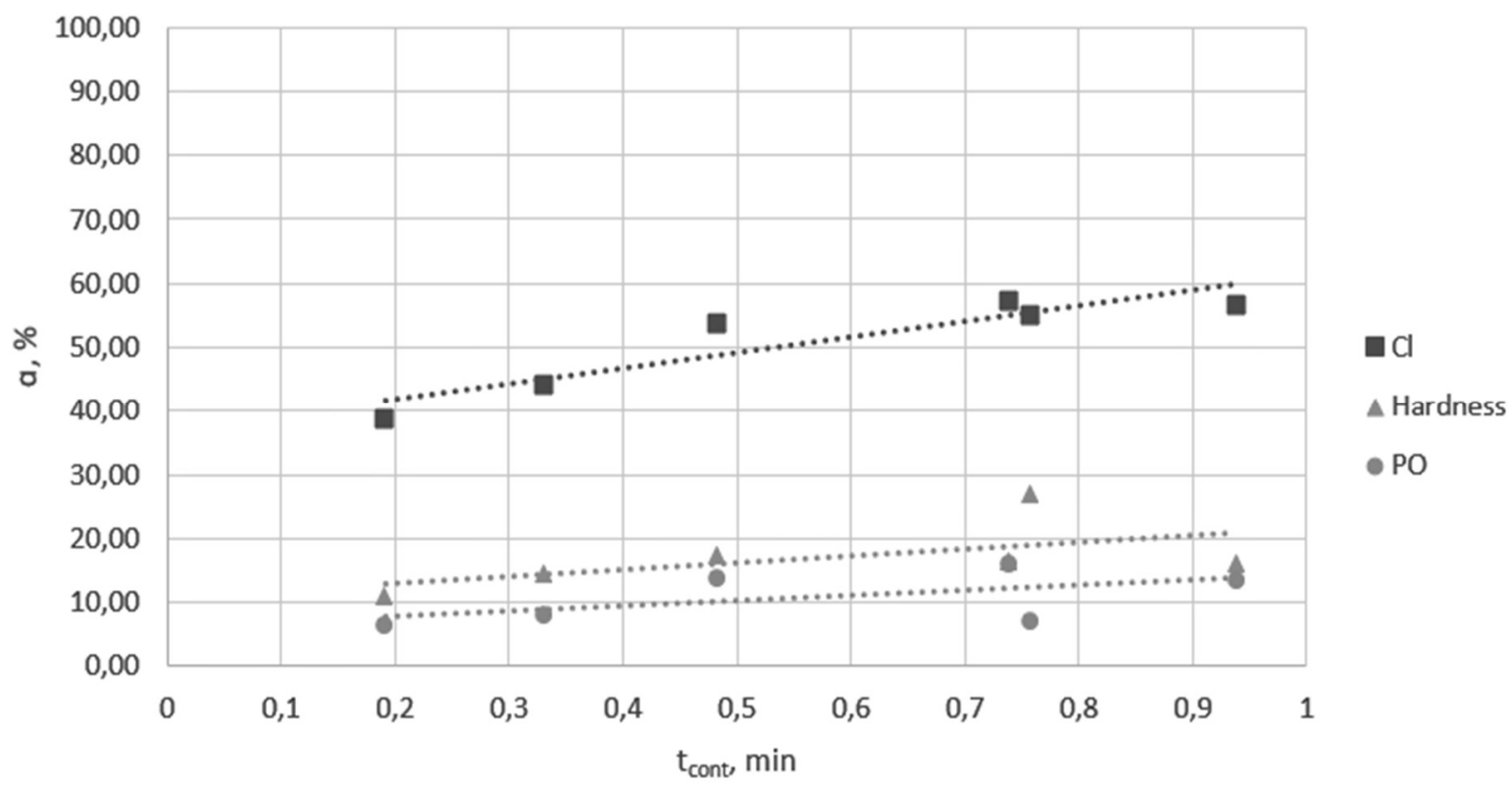

Fig. 4. Effect of contact time (tcont, $\mathrm{min})$ on the efficiency of water purification (a,\%) from chlorine, hardness and PO.

Figure 4 shows that the degree of purification of water from the studied impurities is mainly determined by the contact time of water with the loading of the cartridge. In this case, the contact time of the water with the filtration loading has the greatest effect on the efficiency of water purification from chlorine, while the efficiency of purification from hardness and PO is less significant.

According to the information obtained from the experiment, the following requirements have been formulated, which must be met by a pitcher-filter with optimal properties:

1) The resource of the cartridge, that is filled with a mixture of activated carbon and slightly acid cation exchanger should be $150 \mathrm{dm}^{3}$. The expediency of installing a cartridge resource of 150 $\mathrm{dm}^{3}$ is explained by the fact that after the passed $150 \mathrm{dm}^{3}$ of water, the filtering properties of cartridge loading are significantly reduced due to the depletion of the sorption properties of the materials. So, the regulated content of chlorine in tap water is $0.5 \mathrm{mg} / \mathrm{dm}^{3}$, but to avoid the smell and taste of chlorine when consuming water, its concentration should be no more than $0.2 \mathrm{mg} / \mathrm{dm}^{3}$. Therefore, in order for drinking water to meet this criterion, cartridges must remove at least $60 \%$ chlorine from tap water. However, in the course of the experiment, it became clear that when filtering $150 \mathrm{dm}^{3}$ of water, most of the cartridges remove less than $50 \%$ chlorine, indicating that their resource is depleted by this indicator and therefore inefficient for future use. On the other hand, the resource should not be less than $150 \mathrm{dm}^{3}$, because too low resource will not be attractive to the consumer when choosing a cartridge.

2) The cartridge should remove an average of at least $70 \%$ chlorine during the entire time of operation and at least $60 \%$ per $150 \mathrm{dm}^{3}$ of passed water.

3) To fulfill these conditions the contact time of the water with the filtering loading should be within $0.75-1 \mathrm{~min}$ and the filtration rate should not be less than $100 \mathrm{~cm}^{3} / \mathrm{min}$.

However, in order to create cartridges with optimum properties, there are some important constant and variable factors that affect their performance. 
Permanent factors include:

1) The design parameters of the cartridge, such as:

- Cartridge shape;

- Cartridge height;

- Cartridge volume.

2) Content of active filter components included in cartridge loading, such as:

- Activated coconut shell charcoal;

- Ion exchange material with carboxyl groups;

- Silver-containing component.

The variable factors and their dependence are reflected on Fig. 5.

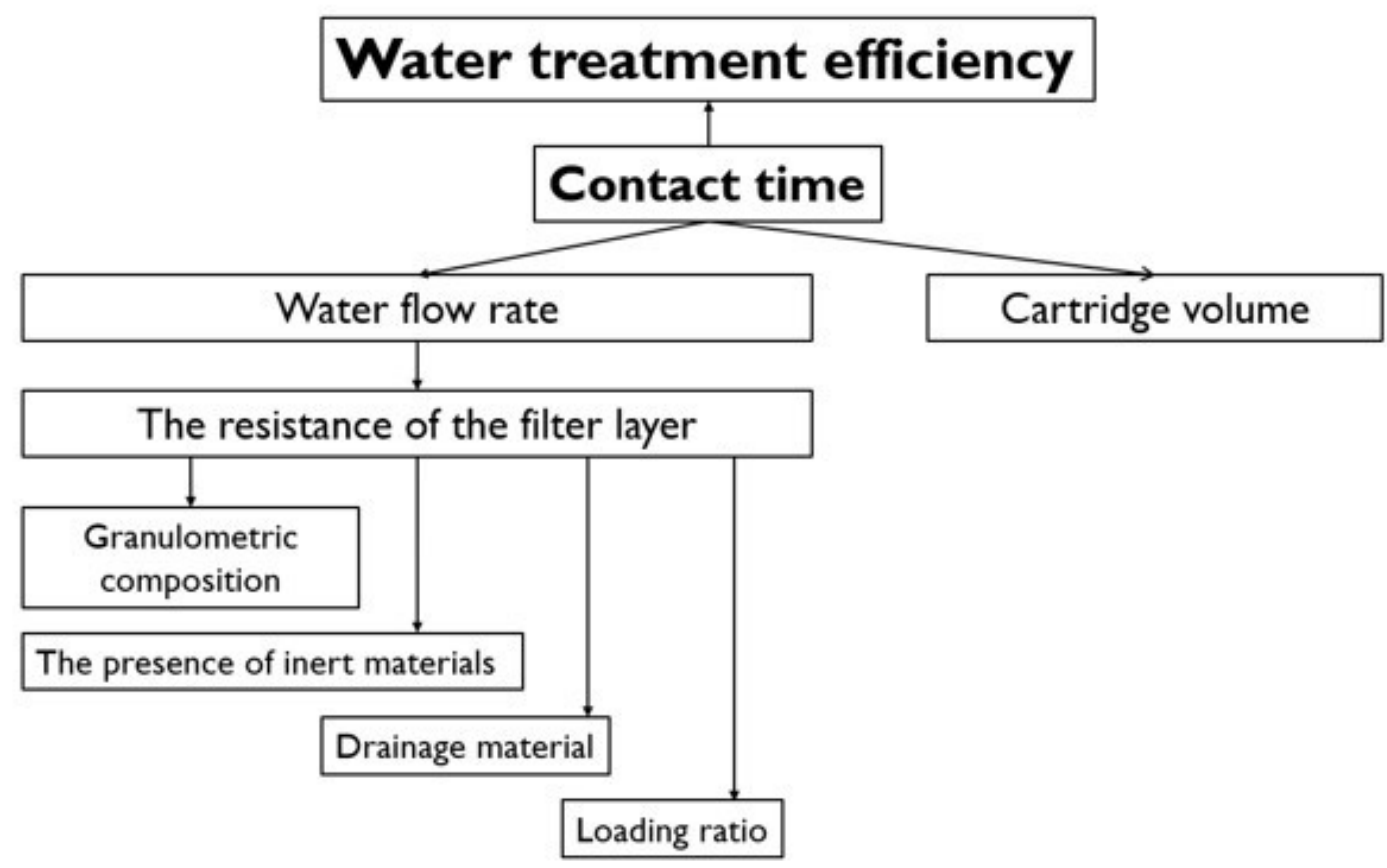

Fig. 5. Variable factors affecting cartridge performance.

\section{Conclusions}

Comparative estimation of cartridges for household filters from different manufacturers showed that, despite the almost identical composition of filter mixtures in different cartridges, the main components of which are coconut activated carbon and slightly acid cation exchanger, their effectiveness in the process of water purification differs significantly. However, the information provided by manufacturers of industrial cartridges about the efficiency of water purification from impurities is untrue, and in fact is overstated.

The main factor influencing the degree of purification of water from chlorine, organic impurities and hardness ions is the contact time of water with the filter loading: the higher the contact time - the higher the degree of purification of water from pollutants. Contact time depends from cartridge volume and water flow rate, which in turn depends from the resistance of the filter layer, which is influenced by granulometric composition of filter loading, the presence of inert materials in it, from the materials of drainage system and loading ratio. By varying, for example, the size of the loading and the flow rate of the solution, you can significantly increase the efficiency of household cartridges for purifying of drinking water. 


\title{
References
}

Bolshak A. P. Improving the efficiency of sorption cartridges for the purification of drinking water. Master's thesis. National Technical University of Ukraine "Igor Sikorsky Kyiv Polytechnic Institute"., Kyiv, 2019 [in Ukrainian].

Bolshak A. P., Mitchenko T. Ye. Assessment of the Efficiency of drinking water treatment with household cartridges. VI International scientific and practical conference "Pure Water. Fundamental, Applied and Industrial Aspects"., 14-15 November, Kyiv, 2019. - P. 73-75 [in Ukrainian].

DSanPin 2.2.4-171-10 State sanitary rules and regulations "Hygienic requirements for drinking water intended for human consumption"., Kyiv 2010 [in Ukrainian].

Maletsky Z.V. Championship pitcher filters. Water and water treatment technologies. Scientific and practical journal., 2012., 64 (4), 4-15 [in Russian].

Mitchenko T. Ye. (Eds.). Series of publications "The World of Modern Water Treatment". Actual problems of water. Kyiv: Ukrainian Water Society WaterNet, 2019 [in Ukrainian]. ISBN 978-96697940-1-7 [in Ukrainian].

Received 28.12.2019

Revised 28.01.2020

Accepted 24.02.2020

\section{ОЦНКА ЕФЕКТИВНОСТІ ДООЧИЩЕННЯ ПИТНОЇ ВОДИ ПОБУТОВИМИ КАРТРИДЖАМИ}

\author{
А. П. Большак ${ }^{1 *}$, Т. С. Мітченко ${ }^{1}$, А. О. Мітченко ${ }^{2}$ \\ ${ }^{1}$ НТУУ «Київський політехнічний інститут ім. І. Сікорського», Київ, Україна \\ ${ }^{2}$ Ecosoft Water International Bvba, Гент, Бельгія \\ *e-mail: annebolshak@gmail.com
}

Мета даного дослідження полягала в порівняльній оцінці роботи картриджів для фільтрглечиків, щуо промислово випускаються. Об'єктами дослідження були 6 зразків картриджів, щзо промислово випускаються п'ятьма відомими виробниками, та є найбільш поширеними на українському ринку. Було вивчено конструкиійні особливості $i$ склад завантаження промислових картриджів для фільтр-глечиків та проведено порівняльне дослідження ефективності їх роботи за показниками очищення води від: хлору, іонів твердості та органічних сполук. Методика експерименту полягала в пропущенні водопровідної води м. Києва через картридж фільтр-глечика з відбором проб для аналізу через 10, 50, 100, 150 дм. Крім того, перед аналізом проб води, пропущеної через фільтр-глечик, відбиралися проби вихідної води для аналізу.

Оцінка ефективності досліджених картриджів по відношенню до хлору показала, щзо середній ступінь зниження ичього показнику в інтервалі 1-150 дм пропущеної води складає 3957\% для всіх картриджів. При изьому після пропускання периих 10 дм води, ефективність ії очищення сягає $83 \%$, а після пропускання 150 дм з $^{3}$-30-50\%. Оиінка ефективності досліджених картриджів по відношенню до окиснюваності та твердості показала, щуо ступінь зниження

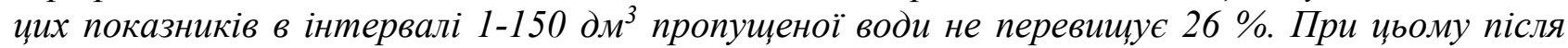
пропускання перших 10 дм $^{3}$ води, ефективність ї̈ очищення від твердості сягає $90 \%$, після пропускання 150 дм $^{3}-6-13 \%$, а при очищенні води від ПО ці показники сягають $30 \%$ після пропускання $10 \mathrm{\partial м}^{3}$ води, i 7-15\% - після пропускання $150 \mathrm{\partial м}^{3}$.

Встановлено, щзо всі досліджені промислові картриджі є фізико-хімічними аналогами $i$ відрізняються лише конструктивними параметрами, а основним фактором, який впливає на ступінь очищення води від забрудників - $\epsilon$ час контакту води з завантаженням картриджу. Було також визначено, щзо інформація, якунадають виробники промислових картриджів, про ефективність очищення води від домішок не відповідає дійсності, i по факту є завищеною. Аналіз інформачії щодо роботи промислових картриджів показав можливість суттєвого 
підвищення їхньої ефективності за рахунок створення оптимальних умов експлуатації. Були сформульовані вимоги, яким має відповідати картридж для фільтр-глечика з оптимальними властивостями і визначені основні змінні і постійні фактори, щуо впливають на ефективність роботи картриджів.

Ключові слова: фільтр-глечик, картридж, слабокислотний катіоніт, активоване вугілля, хлор, твердість води, органічні сполуки, час контакту, ефективність очищення води.

\title{
ОЦЕНКА ЭФФЕКТИВНОСТИ ДООЧИСТКИ ПИТЬЕВОЙ ВОДЫ БЫТОВЫМИ КАРТРИДЖАМИ
}

\author{
А. П. Большак ${ }^{1 *}$, Т. Е. Митченко ${ }^{1}$, А. А. Митченко ${ }^{2}$ \\ ${ }^{1}$ НТУУ «Киевский политехнический институт имени Игоря Сикорского», Киев, Украина \\ ${ }^{2}$ Ecosoft Water International Bvba, Гент, Бельгия \\ *e-mail: annebolshak@gmail.com
}

Цель данного исследования заключалась в сравнительной оченке работы промышленно выпускаемых картриджей для фильтр-кувшинов. Были изучены конструкционные особенности и состав загрузки промышленных картриджей для фильтр-кувшинов $и$ проведено сравнительное исследование эффективности их работы по показателям очистки воды от: хлора, ионов жесткости и органических соединений. Были сформулированы требования, которым должен отвечать картридж для фильтра-кувшина с оптимальными свойствами и определены основные переменные и постоянные факторы, влияющие на эффективность работь картриджей.

Ключевые слова: фильтр-кувиин, картридж, слабокислотный катионит, активированный уголь, хлор, жесткость воды, органические соединения, время контакта, эффективность очистки воды. 